\title{
Evaluation of Ascorbic Acid Contents in Selected Fruits using Iodometric method and UV Spectrophotometer
}

\author{
${ }^{1}$ Adewole Ezekiel, ${ }^{10 j o}$ Abiodun, ${ }^{2}$ Talabi Justina, ${ }^{1}$ Adewumi Funmilayo and ${ }^{1}$ Peters Omolara \\ ${ }^{1}$ Adewole Ezekiel, Dr, senior lecturer, Department of Chemical Sciences, Afe Babalola University Ado, Ekiti state, Nigeria. \\ ${ }^{1}$ Ojo A, Professor, Department of Chemical Sciences, Afe Babalola University Ado, Ekiti state, Nigeria. \\ ${ }^{1}$ Adewumi Funmilayo, Lecturer II, Department of Chemical Sciences, Afe Babalola University Ado, Ekiti state, Nigeria. \\ ${ }_{1}^{1}$ Peters Omolara ${ }^{1}$ Senior Technologist, Department of Chemical Sciences, Afe Babalola University Ado, Ekiti state, Nigeria. \\ ${ }^{2}$ Talabi Justina, Lecturer I, Department of Human Nutrition and Dietetics, Afe Babalola University Ado, Ekiti state, Nigeria.
}

Correspondence Author: Adewole Ezekiel, Afe Babalola University Ado, Department Chemical Sciences, college of sciences, km 8.5, Afe Babalola way, Ado Ekiti, Ekiti State, Nigeria.

E-mail: adewolen50@yahoo.com

Received date: 11 February 2018, Accepted date: 15 May 2018, Online date: 29 May 2018

Copyright: (c) 2018 Adewole Ezekiel et al. This is an open-access article distributed under the terms of the Creative Commons Attribution License, which permits unrestricted use, distribution, and reproduction in any medium, provided the original author and source are credited.

\begin{abstract}
Background: Vitamin C being an essential vitamin in the body is important for physiological functions of the body and this cannot be synthesized in the body, hence the need for the intake of fruits as supplier of vitamin C in the body. There are many fruits available locally in Ado Ekiti, Nigeria and sufficient information are not available using the iodometric and Uv spectrophotomer methods in estimating the ascorbic acid contents simultaneously. Objective: The needs to quantify the ascorbic acid contents of five selected fruits using iodometric and Uv-spectrophotometer methods necessitated the research work and compare the results with the Recommended Dietary Allowance (RDA\} Results: The results of the analysis using iodometric method indicated that the citrus limon had $\left(34.53 \pm 0.08^{\mathrm{c}} \mathrm{mg} / 100 \mathrm{~g}\right)$, vitis vinifera $\left(15.35 \pm 0.01^{\mathrm{b}} \mathrm{mg} / 100 \mathrm{~g}\right)$, malus pumila $\left(11.51 \pm 0.07^{\mathrm{a}} \mathrm{mg} / 100 \mathrm{~g}\right)$, citrullus lanatus $\left(11.51 \pm 0.01^{\mathrm{a}} \mathrm{mg} / 100 \mathrm{~g}\right)$ and ananas comosus $\left.11.51 \pm 0.05^{\mathrm{a}} \mathrm{mg} / 100 \mathrm{~g}\right)$. The Uv spectrophotometer method indicated the values as malus pumila $\left(19.19 \pm 0.48^{\mathrm{c}} \mathrm{mg} / \mathrm{ml}\right)$, citrus limon $\left(18.09 \pm 0.29^{\mathrm{c}} \mathrm{mg} / \mathrm{ml}\right)$, ananas comosus $\left(9.57 \pm 0.53^{\mathrm{b}} \mathrm{mg} / \mathrm{ml}\right)$, vitis vinifera $\left(9.17 \pm 0.21^{\mathrm{b}} \mathrm{mg} / \mathrm{ml}\right)$, and citrullus lanatus $\left(4.20 \pm 0.07^{\mathrm{c}} \mathrm{mg} / \mathrm{ml}\right)$. The values obtained are in the range of Recommended Dietary Allowance (RDA) which is essential for the optimum functions of body growth and development. Conclusion: The iodometric and the Uv spectroscopy methods used for the analysis has shown the various contents of ascorbic acids in the five fruits. The results had shown that the fruits were rich in ascorbic acid and can adequately cater for any deficiency that may arise from lack of vitamin C.
\end{abstract}

Key words: Ascorbic acid, iodometric, Uv spectrophotometer, RDA

\section{INTRODUCTION}

Fruits are well noted to be a very good sources of vitamin C and there are different methods of estimating the content of this vitamin C in the fruits, the iodometric and Uv spectrophotometer methods are being employed to evaluate the vitamin C contents in the selected fruits. It has being well documented the importance of ascorbic acid which has its trade name as vitamin $\mathrm{C}$ in the body by performing various biochemical reactions in the body that involves oxidation and by speeding up the conversion of certain proline residue in collagen to hydroxyproline in the course of collagen synthesis [1]. Vitamin C is an essential nutrient and among its physiological functions includes repair of body tissue, as antioxidant and treatment of scurvy

\section{MATERIALS AND METHODS}

Plant source: The plants were bought from a local market in Ado Ekiti, Ekiti State, Nigeria and authentication of the plant names were done at the Federal University of Technology Akure, Department of Crop and Pest.

Iodine titration:

Titration of standard VC solution:

$20 \mathrm{ml}$ of vitamin C standard solution and $1 \mathrm{ml}$ of starch indicator solution were poured into a $50 \mathrm{ml}$ Erlenmeyer flask. The iodine titration solution was set up into $50 \mathrm{ml}$ burette on the ring stand. The initial volume of the iodine titration solution in the burette was noted. The Erlenmeyer flask (containing the vitamin $\mathrm{C}$ and starch solutions) was placed under the burette. The spring clamp of the burette was carefully released to add iodine solution drop by drop. The flask was swirled to mix the solution after each addition. The titration was considered complete when the iodine created a blue-back colour in the solution that lasted for longer than 20 seconds. The final volume of the iodine solution in the burette was recorded. The difference between the initial volume and the final volume was calculated which was the amount of iodine titration solution needed to oxidize the vitamin $\mathrm{C}$. The procedure was repeated three times. The amount of vitamin $\mathrm{C}$ needed to reduce 
$1 \mathrm{ml}$ of the iodine solution was calculated and used as constant to calculate the amount of the vitamin in unknown samples. Amount of vitamin C needed to reduce $1 \mathrm{ml}$ of dye was calculated by dividing the amount of vitamin $\mathrm{C}$ present in the standard solution by the number of ml of dye titrated.

Titration of sample solution:

Titration of botanical samples were carried out in a quite similar was as that of the vitamin $\mathrm{C}$ standard titration. $20 \mathrm{ml}$ aliquot of the sample solution was pipette into a $50 \mathrm{ml}$ conical flask and $1 \mathrm{ml}$ of starch indicator solution was added. The sample was titrated with $0.005 \mathrm{~mol} / \mathrm{L}$ iodine solution. The endpoint of the titration was identified as the first permanent trace of a dark blue-black colour due to the starch-iodine complex.

The titration was repeated with further aliquots of sample solution until concordant results were obtained. The end point of titration in case of plant sample varies according to the colour of the extract used.

Formula for calculation:

\section{$\frac{\text { AVGTITREVA LUE }- \text { BLANK }}{\text { STANDARDAS CORBICACID }} \times$ DILUTIONFA CTOR $\times 2$}

Spectrophotometric determination:

Experimental Procedure:

Standard vitamin C solution was prepared by dissolving $40 \mathrm{mg}$ of vitamin C in $250 \mathrm{ml}$ of 5\% TCA and designated as stock solution. $10 \mathrm{ml}$ of this solution were pipette out into $100 \mathrm{ml}$ of standard flask and the volume was made up to the mark by adding 5\% TCA solution. This solution was kept as working standard solution. A series of 0-1 ml of working standard solution was pipette out into 6 clean and dry test tubes. The solution in each test tube was made up to $1 \mathrm{ml} 5 \%$ TCA. $1 \mathrm{ml}$ of 2, 4-dinitophynyle hydrazine (DNPH) reagent was added to each test tube and latter were boiled for 8-10 minutes in water bath. The test tubes were cooled and $8 \mathrm{ml}$ of $65 \% \mathrm{H}_{2} \mathrm{SO}_{4}$ were added. The solution in each of the test tubes was mixed well and optical density (O.D) was taken at 540nm using Digital Spectrophotometer .A known quantity from each of the botanical extracts was taken into clean and dry test tubes in three replications in a series of dilutions. The solution in each test tube was made up to $1 \mathrm{ml}$ with 5\% TCA. $1 \mathrm{ml}$ of DNPH reagent was added to each test tube and latter were boiled for 8-10 minutes in water bath. The test tubes were cooled and $8 \mathrm{ml}$ of $65 \% \mathrm{H}_{2} \mathrm{SO}_{4}$ were added. The solution in each of the test tubes was mixed well and optical density (O.D) was taken at $540 \mathrm{~nm}$.

Calculations:

Amount of vitamin $\mathrm{C}$ needed to be read by a unit optical density (OD) was calculated and kept as standard (constant) to measure the amount of vitamin C in an unknown sample. The calculation was directly made using the values of standard vitamin $\mathrm{C}$ constant. Amount of vitamin $\mathrm{C}$ in an unknown was calculated as follows:

$$
\text { Amount of VC in an unknown }=\text { O.DofSample } \times \frac{\text { amountofstan dardVC }}{\text { O.Dofsample }}
$$

Results:

Table 1: showing ascorbic acid content using iodometric method

Fruits

Apple (Malus pumila)

Grape( Vitis Vinifera)

Water Melon (Citrullus Lanatus)

Pineapple (Ananas Comosus)

Lemon (Citrus Limon)

Ascorbic acid $(\mathrm{mg} / 100 \mathrm{~g})$

$11.51+0.07^{\mathrm{a}}$

$15.35 \pm 0.01^{\mathrm{b}}$

$11.51 \pm 0.01^{\mathrm{a}}$

$11.51 \pm 0.05^{\mathrm{a}}$

$34.53+0.08^{\mathrm{c}}$

Table 2: Showing the ascorbic acid contents using Uv Spectrophotometer

Fruits

Apple (Malus pumila)

Grape( Vitis Vinifera)

Water Melon (Citrullus Lanatus)

Pineapple (Ananas Comosus)

Lemon (Citrus Limon)

Results represented in mean \pm standard error at $\mathrm{P}<0.05$

Discussion:

From the result of table 1, it shows that the ascorbic acid content in Malus pumila is $11.51 \mathrm{mg} / 100 \mathrm{~g}$ which is higher than the literature value $6 \mathrm{mg} / 100 \mathrm{~g}$ as recorded by [2]. The RDA is $6 \mathrm{mg} / 100 \mathrm{~g}$ per day as reported by [3]. This shows that Malus pumila is rich in vitamin C content. Also, the experimental value of Vitis Vinifera $15.35 \mathrm{mg} / 100 \mathrm{~g}$ is lower than the

literature value $35.23 \mathrm{mg} / 100 \mathrm{~g}$, the variation in the result may be due to environmental factor such as soil property, where the fruit was planted, however, $15.35 \mathrm{mg} / 100 \mathrm{~g}$ of Vitis Vinifera falls within the RDA and it shows that it is good. Citrullus Lanatus has $11.51 \mathrm{mg} / 100 \mathrm{~g}$ of vitamin C content and this result is higher than literature value $10 \mathrm{mg} / 100 \mathrm{~g}$ [4]. It is higher than the RDA. It indicates that Citrullus Lanatus obtained in Ado Ekiti is rich in vitamin C and this may be due to soil nutrient enrichment. Ananas Comosus also has $11.51 \mathrm{mg} / 100 \mathrm{~g}$ of vitamin C content and which is lower than that of the literature value $12 \mathrm{mg} / 100 \mathrm{~g}$. The RDA is $12 \mathrm{mg} / 100 \mathrm{~g}$, however, $11.51 \mathrm{mg} / 100 \mathrm{~g}$ of Ananas Comosus falls within the RDA and it shows that it is good. The experimental value of lime is $34.53 \mathrm{mg} / 100 \mathrm{~g}$ which is lower than the Recommended Dietary Allowance (RDA) of $46 \mathrm{mg} / 100 \mathrm{~g}$. The variation in the result may be due to the soil property. However, $34.53 \mathrm{mg} / 100 \mathrm{~g}$ of Citrus Limon has the highest experimental value and also falls within the RDA, the value is higher than the citrus reticulata (30.60mg/100g) as reported by [5]. It has been widely reported that ascorbic acid is necessary as an anti-stress and protector against cold, chills and damp reported that Linus Pauling, a Nobel Prize winner in 1970 advocated the use of megadoses (1-3 g/day) of ascorbic acid for the prevention of common cold and related infections. From a preliminary report [6, 7]. The function of ascorbic acid also accounts for its requirement for normal wound healing [6, 7]. In addition, from result of table 2, Malus pumila has the highest Ascorbic acid content $\left(19.19 \mathrm{mg} / \mathrm{ml} \pm 0.48^{\mathrm{c}}\right)$, followed by Citrus Limon $\left(18.09 \mathrm{mg} / \mathrm{ml} \pm 0.29^{\mathrm{c}}\right)$, Pineapple $\left(9.57 \mathrm{mg} / \mathrm{ml} \pm 0.53^{\mathrm{b}}\right)$, Vitis Vinifera $\left(9.17 \mathrm{mg} / \mathrm{ml} \pm 0.21^{\mathrm{b}}\right)$ and Citrullus Lanatus $\left(4.20 \mathrm{mg} / \mathrm{ml} \pm 0.09^{\bar{a}}\right)$.

In comparism, the iodometric titration method indicated Citrus Limon $\left(34.53 \mathrm{mng} / 100 \mathrm{~g} \pm 0.08^{\mathrm{c}}\right)$ has the highest ascorbic acid content while in Uv spectroscopic method, Citrus Limon has appreciable ascorbic acid content $\left(18.09 \mathrm{mg} / \mathrm{ml} \pm 0.29^{c}\right)$. According to [8], Citrus Limon was shown to contain high value of vitamin C when compared with other fruits such as V. Vinifera and C.Sinesis. However, it is well documented that contents of ascorbic acid in fruits could vary due to a lot of factors such factors include temperature, climate, amount of fertilizers $[9,10,11]$.

Conclusion: $\mathrm{mg} / \mathrm{ml}$.

The two methods adopted for the analysis have shown the estimated amount of ascorbic acid present in the selected fruits in different units of $\mathrm{mg} / 100 \mathrm{~g}$ and 
The research work has provided insight into the significance of iodometric and Uv spectrophotometer methods of evaluating ascorbic acid contents in the fruits and more research work need to be done to evaluate the amount of ascorbic acid based on the body mass index which will provide useful information on the quantity to be taken daily.

\section{REFERENCES}

[1] Huise, J.D., S.R. Elli, S.R and L.M. Harderson, 1978. Carnitine biosynthesis Journal of Bio. Chem'., 253.

[2] Romero, M.A., Rodriguez, et al., 1992. Determination of Vitamin C and Organic acids in various fruits by HPLC. Journal of Chromatographic Science., 30: 433-437.

[3] Sidibé, M., J.F. Scheuring, D. Tembely, M.M. Sidibé, P. Hofman and M. Frigg, 1996. Baobab - homegrown vitamin C for Africa'. Agroforestry Today. 8(2): $13-15$.

[4] Levine, M., S.C. Rumsey, R. Daruwala, J.B. Park, Y. Wang, 1999. Criteria and recommendations for vitamin C intake. JAMA. 281: 1415-23.

[5] Adewole E and Talabi, J.Y., 2015. Estimation of percentage of ascorbic acid contents in selected trophical fruits, Annals of Biological Sciences, 3 (2): 5-7

[6] Okwu, D.E., 2004. Journal of Sustainable Agriculture and Environment, 6(1): 30-37.

[7] Okwu, D.E. and M.E. Okwu, 2004. Journal of Sustainable Agriculture and the Environment', 6(2): 140-147.

[8] Shrestha, N., S. Shrestha and A. Bhattarai, 2015. Determination of Ascorbic Acid in Different Citrus Fruits of Kathmandu Valley. J Med Biol Sci Res., 2(1): 9-14: 2449-1810.

[9] Mahdavi, R., Z. Nikniaz, M. Rafraf, A. Jouyban, 2010. Determination and comparison of total polyphenol and vitamin C contents of natural fresh and commercial fruit juices. Pak. J. Nutri. 9(10): 968-972.

[10] Tareen, H., F. Mengal, Z. Masood, R. Mengal, S. Ahmed, S. Bibi, S. Shoaib, U. Sami, F. Mandokhail, M. Riaz, N. Farmanand, Z. Nawaz, 2015. Determination of vitamin $\mathrm{C}$ content in citrus fruits and in non-citrus fruits by titrimetric method, with special reference to their nutritional importance in Human diet. Biological Forum- An. Int. J. 7(2): 367-369.

[11] Bekele, D.A., G.S. Geleta, 2015. Iodometric determination of the ascorbic acid (vitamin C) content of some fruits consumed in Jimma Town Community in Ethiopia. Res. J. Chem. Scis., 5(1): 60-63. 